\title{
DNA-cellulose: An economical, fully recyclable and highly effective chiral biomaterial for asymmetric catalysist
}

Erica Benedetti, ${ }^{a}$ Nicolas Duchemin, ${ }^{a}$ Lucas Bethge, ${ }^{b}$ Stefan Vonhoff, ${ }^{b}$ Sven Klussmann, ${ }^{b}$ Jean-Jacques Vasseur, ${ }^{c}$ Janine Cossy, ${ }^{a}$ Michael Smietana ${ }^{c, *}$ and Stellios Arseniyadis ${ }^{a, *}$

The challenge in DNA-based asymmetric catalysis is to perform a reaction in the vicinity of the helix by incorporating a smallmolecule catalyst anchored to the DNA in a covalent, dative, or non-covalent yet stable fashion in order to insure high levels of enantio-discrimination. Here, we report the first generation of a DNA-based catalyst bound to a cellulose matrix. The chiral biomaterial is commercially available, trivial to use, fully recyclable and produces high levels of enantioselectivity on various $\mathrm{Cu}$ (II)-catalyzed asymmetric reactions including FriedelCrafts alkylations and Michael additions. A single-pass, continuous-flow process is also reported affording fast conversions and high enantioselectivities at low catalyst loadings thus offering a new benchmark in the field of DNAbased asymmetric catalysis.

DNA-based asymmetric catalysis offers great promise in the advancement of enantioselective artificial biohybrid-mediated catalysis. Introduced in 2005 by Roelfes and Feringa, ${ }^{1}$ the concept has been since then successfully applied to a wide variety of copper(II)-catalyzed carbon-carbon, carbon-heteroatom and carbonhalogen bond forming reactions. ${ }^{2-14}$ While still in its early stage, the field is rapidly expanding with studies dedicated to DNA secondary structures, ${ }^{15-18}$ DNA solvatation ${ }^{19-21}$ and to new anchoring strategies. ${ }^{22-25}$ In this context, we recently reported the first example of a left-helical enantioselective induction using L-nucleic acids. The method allowed a reliable and predictable access to both enantiomers for a given reaction. ${ }^{26}$

With the prospect of being used widely by both academic and industrial organic chemists, DNA-based asymmetric catalysis is now facing scale and catalyst-recovery issues. While up to $2.4 \mathrm{mmol}$ scale reactions have been reported albeit using large amounts of DNA, ${ }^{6,19}$ there is to the best of our knowledge only one example featuring a recyclable solid-supported DNA. Indeed, Park, Sugiyama and co-workers recently synthesized an ammonium-functionalized silica that was used to immobilize salmon testes DNA (st-DNA) through electrostatic interactions. ${ }^{27}$ Evaluated in the enantioselective Diels-Alder reaction, both the conversion and the ees were in the range of those obtained using standard st-DNA.

In our search of a robust, cheap and reusable solid-supported strategy, we turned our attention to cellulose-supported DNA (CS-DNA, Figure 1). ${ }^{28}$ Indeed, the cellulose frameworks have attracted a lot of attention over the years due to their favourable biophysical properties, biocompatibility, low immunogenicity, relatively high resistance to temperature and relatively low cost. Interestingly, however, while CS-DNA has been widely used to either purify sequence-specific DNA-binding proteins ${ }^{29}$ or to determine binding constants for non-specific interactions between proteins and DNA, ${ }^{30}$ there are no examples of DNA-based asymmetric catalysis involving a cellulose-supported DNA scaffold. This is all the more peculiar that double-stranded calf thymus DNA

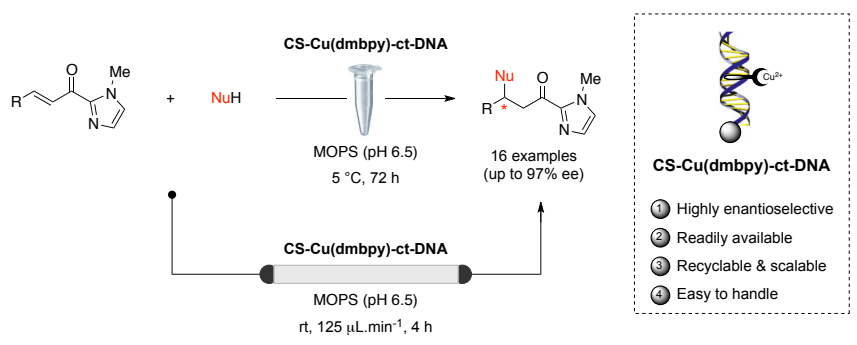

Figure 1. A cellulose-supported (CS) ct-DNA/Cu(dmbpy) biohybrid for DNA-based asymmetric catalysis. [ $\mathrm{NuH}=$ indoles, dimethylmalonate].

(ct-DNA) covalently attached to cellulose is nowadays commercially available from several suppliers. Combined, all these properties made cellulose a particularly appealing solid support with a potential use in DNA-based asymmetric catalysis; we report here the results of our endeavours.

In order to evaluate the efficacy of CS-ct-DNA in DNA-based asymmetric catalysis, we first tested the $\mathrm{Cu}(\mathrm{II})$-catalyzed FriedelCrafts alkylation of $\alpha, \beta$-unsaturated 2-acyl imidazole 1 a $(0.6 \mu \mathrm{mol})$ with 5 -methoxyindole $(3.0 \mu \mathrm{mol})$. The reaction was performed in a $20 \mathrm{mM}$ MOPS buffer ( $\mathrm{pH} \mathrm{6.5)}$ in the presence of 4,4'-dimethyl2,2'-bipyridine (dmbpy, $36 \mathrm{~mol} \%), \mathrm{Cu}\left(\mathrm{NO}_{3}\right)_{2}(30 \mathrm{~mol} \%$ ) and $163 \mathrm{mg}$ of the cellulose-supported double-stranded ct-DNA (4.3 $\mathrm{mg}$ of ct-DNA per g of cellulose) over 3 days at $5{ }^{\circ} \mathrm{C}$. Both the conversion and the ee of the resulting product were determined by supercritical fluid chromatography (SFC) analysis. To our delight complete conversion of the starting enone was observed and the resulting product was obtained in $81 \%$ ee (Table 1 , entry 1 ), which was comparable with the result obtained with unsupported ct-DNA $(80 \%$ ee, Table 1 , entry 2$)$. To ensure that the selectivity obtained was solely due to the supported catalyst and not from any residual DNA that could have potentially leaked from the solid support, the cellulose was filtered, washed with a $20 \mathrm{mM}$ MOPS buffer solution and re-engaged in a second experiment under otherwise identical conditions. Once again, the reaction afforded full conversion of $\mathbf{1 a}$ to the corresponding Friedel-Crafts product $2 \mathbf{a}$ with no noticeable loss in either reactivity or selectivity. Following these initial results and in order to prove that the cellulose itself did not induce the selectivity due to its inherent chirality, a control experiment using standard cellulose was undertaken; the reaction yielded compound 2a in only $12 \%$ ee (Table 1 , entry 3 ). An additional reaction performed with CS-ct-DNA in the absence of dmbpy showcased the importance of the ligand as not only was the product formed in a lower yield but also with barely any selectivity (Table 1, entry 4 ).

With these conditions in hand the reaction was eventually applied to a variety of indoles with different substitution patterns (Table 1, entries 5-7) as well as to a number of $\alpha, \beta$-unsaturated 2-acyl imidazoles (Table 1, entries 8-12). As a general trend, the reaction tolerated both $\mathrm{C} 3$-aliphatic and aromatic substituents on the enone as the corresponding Friedel-Crafts products were obtained in 
Table 1. Friedel-Crafts alkylation with CS-ct-DNA

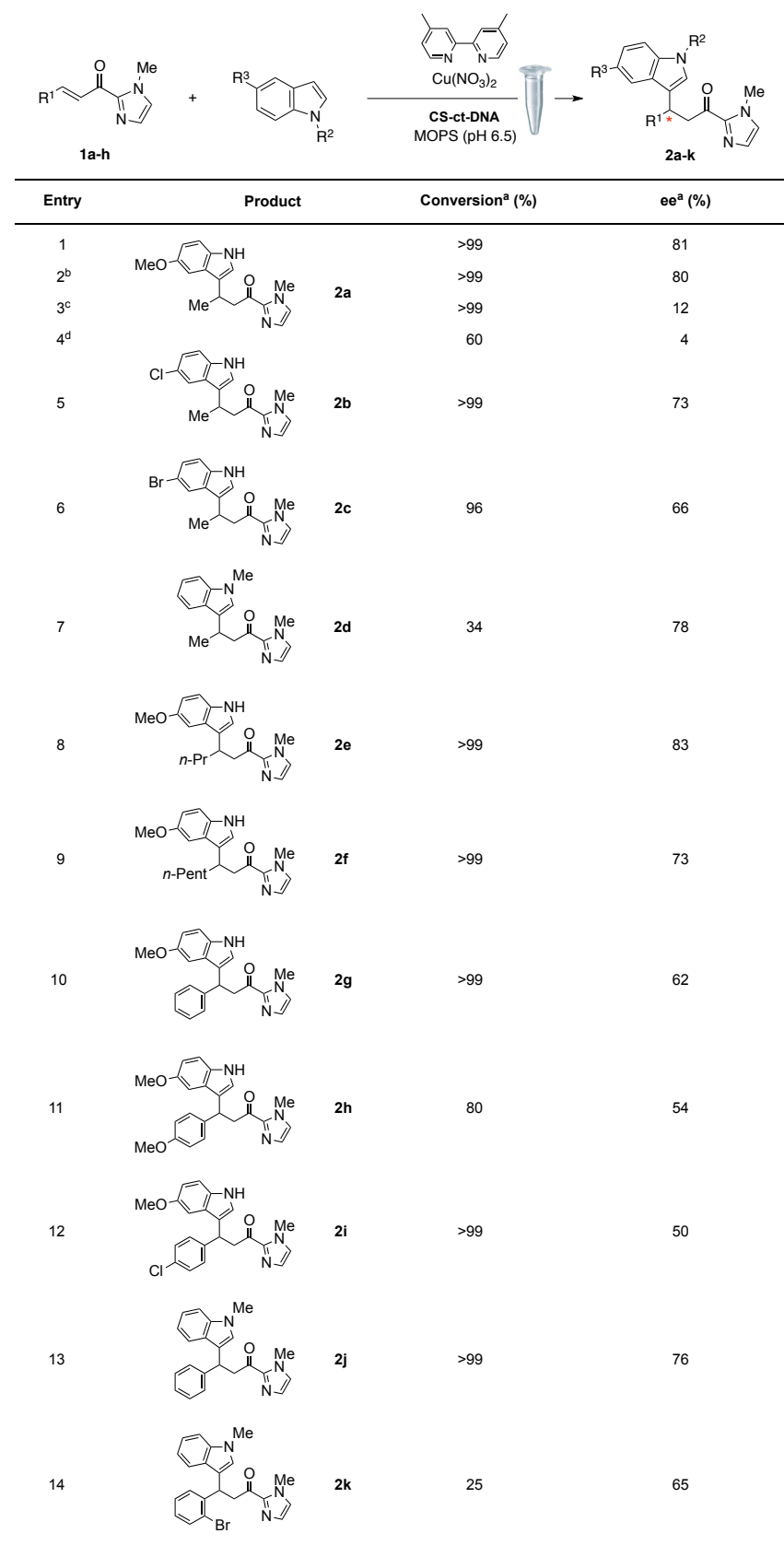

Conditions: $2 \mathrm{mM}$ base pair solution of DNA in a $20 \mathrm{mM}$ MOPS solution $(400 \mu \mathrm{L}, \mathrm{pH} 6.5$ $0.3 \mathrm{mM}$ of $\mathrm{Cu}(\mathrm{dmbpy})\left(\mathrm{NO}_{3}\right)_{2}$ in a $20 \mathrm{mM}$ MOPS solution $(200 \mu \mathrm{L}), 0.5 \mathrm{M}$ solution of enone in $\mathrm{CH}_{3} \mathrm{CN}(1.2 \mu \mathrm{L})$, $2.5 \mathrm{M}$ solution of indole in $\mathrm{CH}_{3} \mathrm{CN}(1.2 \mu \mathrm{L}), 3 \mathrm{~d}, 5^{\circ} \mathrm{C}$. ${ }^{\text {a }}$ Determined by supercritical phase chromatography $(\mathrm{SFC})$ analysis. ${ }^{\mathrm{b}}$ Reaction run using unsupported ct-DNA. ${ }^{\mathrm{c}}$ Reaction run using DNA-free cellulose. ${ }^{\mathrm{d}}$ Reaction run in the abscence of dmbpy.

essentially quantitative yield and with ees ranging from $50 \%$ to $83 \%$ after 3 days at $5{ }^{\circ} \mathrm{C}$. It is worth pointing out however that higher levels of conversion and selectivity were obtained when electronrich indoles were used in conjunction with enones bearing an aliphatic substituent at the $\mathrm{C} 3$ position (Table 1, entries 1 and 8 ).

Prompted by these results, the CS-ct-DNA was also applied to the Michael addition of dimethylmalonate (Table 2). Once again, the products were obtained in high yields and excellent enantioselectivities ranging from $81 \%$ to $97 \%$, even though enones bearing an electron-poor aromatic substituent appeared to be less reactive.
Table 2. Friedel-Crafts alkylation with CS-ct-DNA

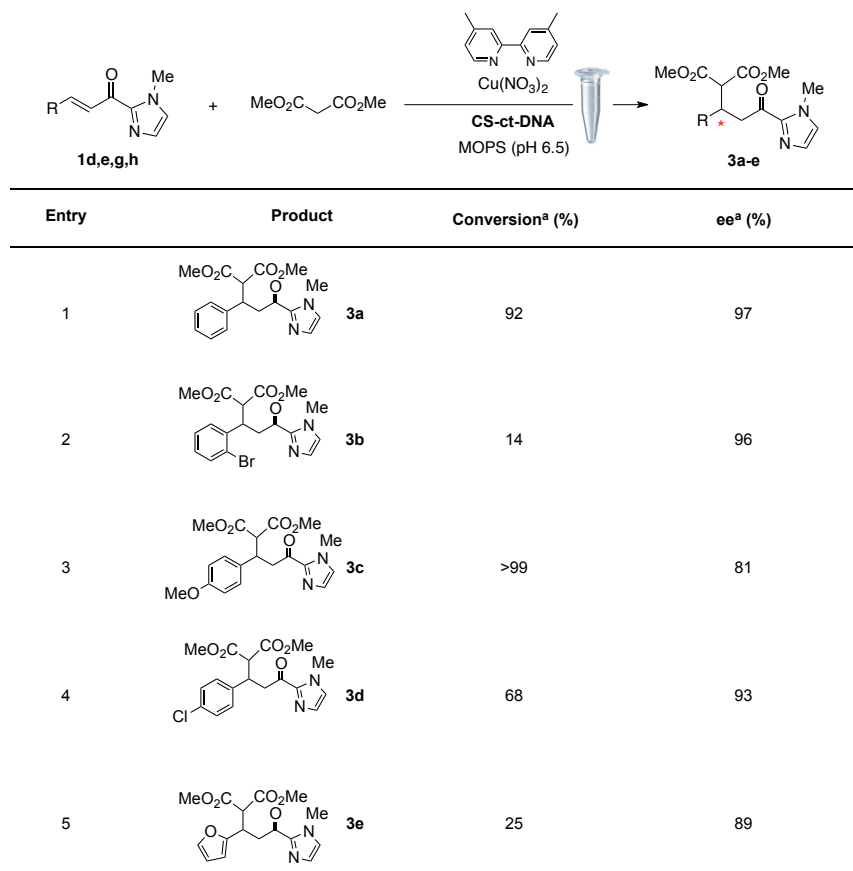

Conditions: $2 \mathrm{mM}$ base pair solution of DNA in a $20 \mathrm{mM}$ MOPS solution (400 $\mu \mathrm{L}, \mathrm{pH} 6.5$ ), $0.3 \mathrm{mM}$ of $\mathrm{Cu}(\mathrm{dmbpy})\left(\mathrm{NO}_{3}\right)_{2}$ in a $20 \mathrm{mM}$ MOPS solution $(200 \mu \mathrm{L}), 0.5 \mathrm{M}$ solution of enone in $\mathrm{CH}_{3} \mathrm{CN}(1.2 \mu \mathrm{L})$, pur malonate $(6.9 \mu \mathrm{L}), 3 \mathrm{~d}, 5^{\circ} \mathrm{C} .{ }^{\mathrm{a}}$ Determined by supercritical phase chromatography (SFC) analysis.
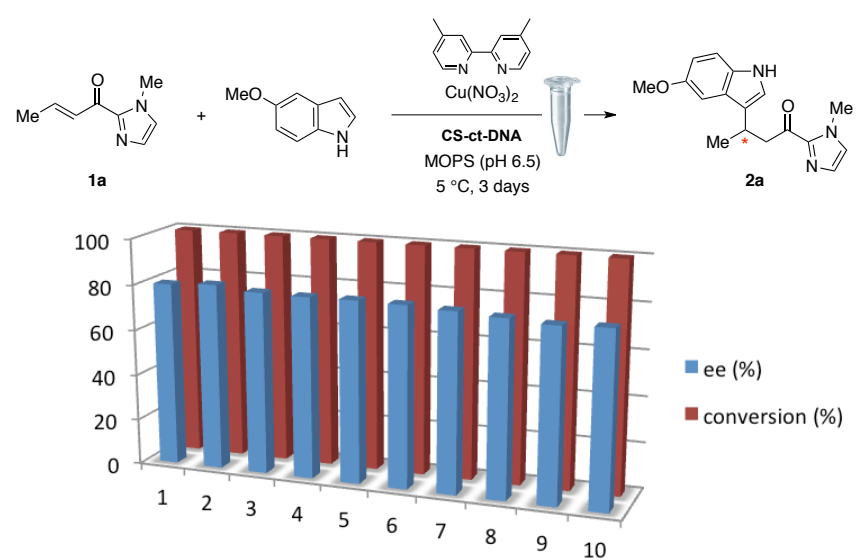

Figure 2. Investigation of the reusability of the CS-ct-DNA-Cu(dmbpy) biohybrid catalyst.

In order to fully investigate the robustness of the catalyst and therefore its recyclability, a series of $\mathrm{Cu}(\mathrm{II})$-catalyzed Friedel-Crafts alkylations were performed using $\alpha, \beta$-unsaturated 2 -acyl imidazole 1a and 5-methoxyindole under the standard conditions $(20 \mathrm{mM}$ MOPS buffer, $\mathrm{pH} 6.5,5^{\circ} \mathrm{C}, 3$ days). After each run, the reaction was filtered and the cellulose was washed with a $20 \mathrm{mM}$ MOPS buffer before being re-used. Interestingly, this recycling procedure could be repeated only up to two times before a slight decrease of the selectivity ( $4 \%$ loss on every cycle) could be observed. This prompted us to consider that the use of additional $\mathrm{Cu}$ and dmbpy in every run could be detrimental if the $\mathrm{Cu}(\mathrm{dmbpy})$ complex was to remain incorporated into the DNA after each filtration. A control experiment using a recycled CS-ct-DNA in the absence of additional $\mathrm{Cu}$ and dmbpy afforded full conversion of the starting enone without any noticeable loss of reactivity or selectivity. Remarkably, under these conditions the cellulose could be recycled up to 10 times 
without adding any $\mathrm{Cu}$ or dmbpy at every run, thus showcasing the affinity of the $\mathrm{Cu}(\mathrm{dmbpy})$ complex with the DNA (Figure 2). ${ }^{31}$ Considering the amount of CS-ct-DNA and $\mathrm{Cu}(\mathrm{dmbpy})$ complex used in the process, this cellulose-supported approach has a clear advantage over the silica-version ${ }^{27}$ as the entire catalytic system is recycled, thus highlighting the potential of DNA-cellulose for largescale applications.

Having demonstrated the efficacy of our immobilized DNAbased biohybrid catalyst in the context of asymmetric catalysis, we next set out to implement the method to a continuous-flow process. $^{32,33}$ The experimental setup consisted of a low-pressure chromatography column which was loaded with the CS-ct-DNA$\mathrm{Cu}$ (dmbpy) biohybrid catalyst and connected to a syringe pump used to feed the reactor with the reagents. As no reaction takes place in the absence of the $\mathrm{Cu}(\mathrm{dmbpy})$ complex, we were able to pump both reagents together in a $20 \mathrm{mM}$ MOPS buffer/MeOH (30:1) solution. ${ }^{34}$ It is worth emphasizing however that this ratio was critical to prevent any loss of selectivity as, for a reason that still remains unclear, higher amounts of $\mathrm{MeOH}$ led to lower ees. Moreover, in order to be effective, we needed to determine the amount of CS-ct-DNA-Cu(dmbpy) biohybrid catalyst as well as the optimal flow-rate required for the reaction to be complete after a single run across the column. When performing the reaction on a $0.03 \mathrm{mmol}$ scale using a $1.1 \mathrm{~g}$ cartridge of CS-ct-DNA at a flow-rate of $0.25 \mathrm{~mL} \cdot \mathrm{min}^{-1}$, the corresponding Friedel-Crafts product was obtained in $80 \%$ ee albeit in only $60 \%$ yield (Table 3 , entry 1 ). By decreasing the flow-rate to $0.125 \mathrm{~mL} \cdot \mathrm{min}^{-1}$ and doubling the length of the column ( $2.2 \mathrm{~g}$ cartridge of CS-ct-DNA), $83 \%$ of the starting material were converted with virtually the same selectivity (Table 3 , entry 2). Eventually, the use of a $4.4 \mathrm{~g}$ cartridge of CS-ct-DNA under otherwise identical conditions led to roughly complete conversion of the starting enone and the alkylated product was obtained in $92 \%$ yield and $79 \%$ ee (Table 3, entry 3). Finally, increasing the reaction scale by a factor 10 appeared not to be detrimental in terms of both conversion and selectivity as the desired Firedel-Crafts product was isolated in $89 \%$ yield and $78 \%$ ee (Table 3, entry 4).

In summary, we have developed a particularly appealing cellulose-supported DNA-based catalyst that offers high levels of enantioselectivity on various $\mathrm{Cu}(\mathrm{II})$-catalyzed asymmetric reactions including Friedel-Crafts alkylations and Michael additions. The system has various advantages. Indeed, the chiral biomaterial is commercially available, particularly robust and trivial to use. In addition, the $\mathrm{Cu}$ (dmbpy) complex bound to the CS-ct-DNA can be fully recycled after each run with no noticeable loss of reactivity or selectivity. Most importantly, the CS-ct-DNA-Cu(dmbpy) biohybrid catalyst can be implemented to a single-pass, continuous-flow process allowing to perform the reactions on a synthetically useful scale using low catalyst loadings. Considering that the grafting can be performed on any selected sequence and DNA configuration, these results will undoubtedly contribute to the development and generalization of DNA-based asymmetric catalysis.

This research was supported by the Ministère de 1'Enseignement Supérieur et de la Recherche and the Agence Nationale de la Recherche (NCiS; ANR-2010-JCJC-715-1).
Table 3. CS-ct-DNA-catalysed Friedel-Crafts under continuous-flow

\begin{tabular}{|c|c|c|c|c|c|c|}
\hline Entry & Scale & $\begin{array}{l}\text { Flow rate } \\
\left(\mathrm{mL} \cdot \mathrm{min}^{-1}\right)\end{array}$ & $\begin{array}{l}\text { CS-ct-DNA } \\
\text { (g) }\end{array}$ & $\begin{array}{l}\text { Residence time } \\
\text { (min) }\end{array}$ & $\begin{array}{c}\text { Conversion }{ }^{\mathrm{a}} \\
(\%)\end{array}$ & $\begin{array}{l}e^{b^{b}} \\
(\%)\end{array}$ \\
\hline 1 & $0.03 \mathrm{mmol}$ & 0.25 & 1.1 & 5 & 60 & 80 \\
\hline 2 & $0.03 \mathrm{mmol}$ & 0.125 & 2.2 & 19 & 83 & 79 \\
\hline 3 & $0.03 \mathrm{mmol}$ & 0.125 & 4.4 & 38 & $96\left(92^{c}\right)$ & 79 \\
\hline 4 & $0.3 \mathrm{mmol}$ & 0.125 & 4.4 & 38 & $96\left(89^{c}\right)$ & 78 \\
\hline
\end{tabular}

\section{Notes and references}

${ }^{a}$ Laboratoire de Chimie Organique, Institute of Chemistry, Biology and Innovation (CBI) - ESPCI ParisTech/CNRS (UMR8231)/PSL* Research University, 10 rue Vauquelin, 75231 Paris Cedex 05, France.

${ }^{b}$ NOXXON Pharma AG. Max-Dohrn-Strasse 8-10, 10589 Berlin, Germany.

${ }^{c}$ Institut des Biomolécules Max Mousseron UMR 5247 CNRSUniversités Montpellier 1 et 2 Place Eugène Bataillon, 34095 Montpellier, France.

$\dagger$ Electronic Supplementary Information (ESI) available: Details of experimental procedures, ${ }^{1} \mathrm{H}$ NMR and ${ }^{13} \mathrm{C}$ NMR spectra as well as SFC chromatograms. See DOI: 10.1039/c000000x/

1 (a) G. Roelfes, B. L. Feringa, Angew. Chem., Int. Ed. 2005, 44, 3230-3232; (b) A. J. Boersma, B. L. Feringa, G. Roelfes, Org. Lett. 2007, 9, 3647-3650.

2 D. Coquiere, B. L. Feringa, G. Roelfes, Angew. Chem., Int. Ed. 2007, 46, 9308-9311.

3 E. W. Dijk, A. J. Boersma, B. L. Feringa, G. Roelfes, Org. Biomol. Chem. 2010, 8, 3868-3873.

4 E. W. Dijk, B. L. Feringa, G. Roelfes, Tetrahedron-Asymmetry 2008, 19, 2374-2377.

5 A. J. Boersma, D. Coquiere, D. Geerdink, F. Rosati, B. L. Feringa, G. Roelfes, Nat. Chem. 2010, 2, 991-995.

6 A. J. Boersma, B. L. Feringa, G. Roelfes, Angew. Chem., Int. Ed. 2009, 48, 3346-3348.

7 A. J. Boersma, J. E. Klijn, B. L. Feringa, G. Roelfes, J. Am. Chem. Soc. 2008, 130, 11783-11790.

8 J. Oelerich, G. Roelfes, Chem. Sci. 2010, 4, 2013-2017.

9 N. Shibata, H. Yasui, S. Nakamura, T. Toru, Synlett 2007, 1153-1157.

10 A. J. Boersma, R. P. Megens, B. L. Feringa, G. Roelfes, Chem. Soc. Rev. 2010, 39, 2083-2092.

11 A. Garcia-Fernandez, G. Roelfes, Met. Ions Life Sci. 2012, 10, 249-268.

12 (a) S. Park, K. Ikehata, R. Watabe, Y. Hidaka, A. Rajendran, H. Sugiyama, Chem. Commun. 2012, 48, 10398-10400; (b) G. P. Petrova, Z. Ke, S. Park, H. Sugiyama, K. Morokuma, Chemical Physics Letters 2014, 600, 87-95.

13 J. Bos, G. Roelfes, Curr. Opin. Chem. Biol. 2014, 19, 135-143. 
14 Y. Li, C. Wang, G. Jia, S. Lu, C. Li, Tetrahedron 2013, 69, 6585-6590.

15 M. Wilking, U. Hennecke, Org. Biomol. Chem. 2013, 11, 6940-6945.

16 S. Roe, D. J. Ritson, T. Garner, M. Searle, J. E. Moses, Chem. Commun. 2010, 46, 4309-4311.

17 C. Wang, G. Jia, J. Zhou, Y. Li, Y. Liu, S. Lu, C. Li, Angew. Chem., Int. Ed. 2012, 51, 9352-9355.

18 C. H. Wang, Y. H. Li, G. Q. Jia, Y. Liu, S. M. Lu, C. Li, Chem. Commun. 2012, 48, 6232-6234.

19 H. Zhao, K. Shen, RSC Adv. 2014, 4, 54051-54059.

20 (a) R. P. Megens, G. Roelfes, Chem. Commun. 2012, 48, 6366-6368; (b) R. P. Megens, G. Roelfes, Org. Biomol. Chem. 2010, 8, 1387-1393.

21 F. Rosati, J. Oelerich, G. Roelfes, Chem. Commun. 2010, 46, 7804-7806.

22 F. Rosati, A. J. Boersma, J. E. Klijn, A. Meetsma, B. L. Feringa, G. Roelfes, Chem. Eur. J. 2009, 15, 9596-9605.

23 S. Park, L. Zheng, S. Kumakiri, S. Sakashita, H. Otomo, K. Ikehata, H. Sugiyama, ACS Catal. 2014, 4, 4070-4073.

24 A. J. Boersma, B. de Bruin, B. L. Feringa, G. Roelfes, Chem. Commun. 2012, 48, 2394-2396.

25 L. Gjonaj, G. Roelfes, Chem CatChem 2013, 5, 1718-1721.

26 J. Wang, E. Benedetti, L. Bethge, S. Vonhoff, S. Klussmann, J.-J. Vasseur, J. Cossy, M. Smietana, S. Arseniyadis, Angew. Chem., Int. Ed. 2013, 52, 11546-11549.

27 S. Park, K. Ikehata, H. Sugiyama, Biomater. Sci. 2013, 1, 1034-1036.

28 S. Biagioni, R. Sisto, A. Ferraro, P. Caiafa, C. Turano, Anal. Biochem. 1978, 89, 616-619.

29 J. T. Kadonaga, R. Tjian, Proc. Natl. Acad. Sci. USA, 1986, 83, 5889-5893.

30 P. L. deHaset, C. A. Gross, R. R. Burgess, M. T. Record, Biochemistry 1977, 16, 4777-4783.

31 This corresponds to an accumulated turnover number (TON) of over 300 .

32 (a) J. Wegner, S. Ceylan, A. Kirschning, Adv. Synth. Catal. 2012, 354, 17-57; (b) B. P. Mason, K. E. Price, J. L. Steinbacher, A. R. Bogdan, D. T. McQuade, Chem. Rev. 2007, 107, 2300-2318; (c) J. Hartwig, J. B. Metternich, N. Nikbin, A. Kirschning, S. V. Ley, Org. Bio. Chem. 2014, 12, 3611-3615; (d) J. C. Pastre, D. L. Browne, S. V. Ley, Chem. Soc. Rev. 2013, 42, 8801-8869.

33 (a) P. J. Nieuwland, R. Segers, K. Koch, J. C. M. van Hest, F. P. J. Rutjes, Org. Process Res. Dev. 2011, 15, 783-787; (b) For a recent review on the combination of heterogeneous catalysis with microreactor technology, see: (a) C. G. Frost, L. Mutton, Green Chem. 2010, 12, 1687-1703; (b) R. M. Myers, K. A. Roper, I. R. Baxendale, S. V. Ley in Modern Tools for the Synthesis of Complex Bioactive Molecules (Ed. J. Cossy, S. Arseniyadis), J. Wiley, New York, ISBN 978-0-470-61618-5, 2012, Ch 11, p. 359-394. (c) J. Hartwig, J. B. Metternich, N. Nikbin, A. Kirschning, S. V. Ley, Org. Bio. Chem. 2014, 12, 3611-3615.

34 The addition of a small amount of $\mathrm{MeOH}$ was necessary in order to obtain a homogeneous solution of both reactants without observing any loss of selectivity (see Supporting Information for more details). 


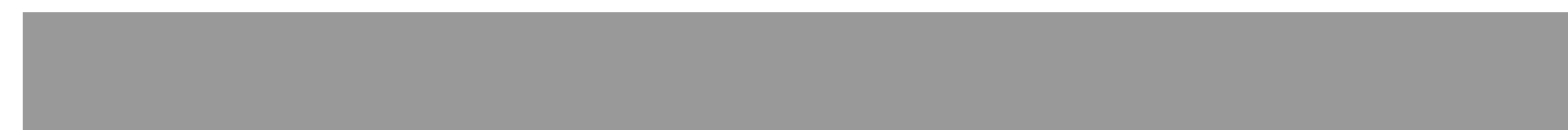

